\title{
Editorial: The Mediocrity of Things
}

'The Directory in Paris, putting on the air of a well-established sovereign, revealed a total hatred of anything not mediocre.' Thus Stendhal; but for the Parisian Directory substitute the government of M- or B-, or nearer home, perhaps, the senate of University X, and doubtless a frisson of recognition flutters either in one's own breast, or in that of one's hearers. If we were honest most of us would admit to having at one time or another been consoled by such a Stendhalian thought, even if we lack his style in expressing it. But we should remember that just as we are thinking this about others, others may be having just the same thought about us as we put on our airs of authority and importance.

We should also remember, as did Stendhal, what followed the Directory, but possibly not with the same affection as Stendhal. Stendhal's two great heroes, Julien Sorel and Fabrice del Dongo, were, as was Stendhal himself, devotees of Napoleon and of the Napoleonic myth. Julien particularly lifted himself from the mediocrity of his village life by his assiduous cultivation of the myth and of the Napoleonic personality. But both he and Fabrice eventually foundered fatally in their quest. Stendahl, too, his devasting insights into the weaknesses of others should have known better. Unlike Fabrice at Waterloo, he did find his hero and his battles, having himself been on the retreat from Moscow.

The twentieth century, too, saw leaders of Napoleonic charisma and destructiveness. Even to-day we are puzzled by the fact that a significant proportion of those attracted to extremism and terrorism are not the wretched of the earth, as common sense might predict, but actually well educated and well qualified, doctors, architects, engineers and the like. Stendhal and his heroes give us a clue. It is precisely the well educated and imaginative youth who feels the oppression of the mediocre mentality which surrounds him or which he feels surrounds him, and by contrast, the lure of the Napoleonic figure, extending even to his capacity to destroy, whatever the putative cause. 